\title{
IMAJINASI BERBASIS GENDER (PENAFSIRAN ATAS MODEL PEREMPUAN DALAM IKLAN)
}

\author{
Prayanto Widyo Harsanto \\ Desain Komunikasi Visual, Fakultas Seni Rupa \\ Institut Seni Indonesia Yogyakarta \\ prayantowh@ymail.com
}

\begin{abstract}
Abstrak
Iklan adalah hasil kebudayaan modern disadari atau tidak mempengaruhi tingkah laku masyarakat. Model perempuan yang digunakan sebagai model iklan dapat membangkitkan daya tarik pada pandangan pertama, dimana hal ini sesuai yang diharapkan sebuah iklan adalah mampu menarik perhatian. Tujuan penelitian ini untuk melihat peran perempuan dalam iklan. Pendekatan visual methodologies dari Gillian Rose digunakan pada kajian ini, dimana iklan dalam sebuah kajian merupakan objek material yang berupa artefak yang utamanya bisa dilihat, diamati melalui indera penglihatan. Hasil kajian ini tampak perempuan berfungsi sebagai nyawa dari suatu produk atau jasa yang ditawarkan dan perempuan digunakan sebagai obyek utama untuk membangkitkan daya tarik erotik terhadap sebuah produk, sehingga produk yang ditawarkan diharapkan mampu terjual atau mampu mendongkrak penjualan.
\end{abstract}

Kata kunci: iklan, perempuan, citra

\begin{abstract}
Advertising is the result of modern culture realized or does not affect the behavior of society. The female model used as an advertising model can generate attraction at first glance, where it is as expected an ad is capable of attracting attention. The purpose of this study is to look at the role of women in advertising. Gillian Rose's visual methodologies approach is used in this study, where the advertisement in a study is a material object in the form of an artifact that is primarily visible, observed through the sense of sight. The results of this study show that women function as lives of a product or service offered and women are used as the main object to generate erotic attractiveness of a product, so that the products offered are expected to be sold or able to boost sales.
\end{abstract}

Keywords: ads, women, imagery

\section{Pendahuluan}

Dikatakan Herbert Marcuse ideologi konsumerisme mendorong kebutuhan palsu dan bahwa kebutuhan ini akan bekerja sebagai satu bentuk kontrol sosial "orang-orang itu akan mengenali diri mereka di dalam komoditas, mereka menemukan jiwa di dalam mobil, perangkat $\mathrm{Hi}-\mathrm{Fi}$, dan rumah mewah “ (John Storey, 2008: 145). Jadi pengiklan 
mendorong kebutuhan palsu - misalnya keinginan seseorang untuk menggunakan pakaian tertentu, barang-barang tertentu, minuman tertentu, parfum tertentu seperti yang pernah dilihat pada iklan.

Iklan dengan berbagai macam penampilan dan bentuknya, pada dasarnya berfungsi untuk memberi informasi tentang produk barang atau jasa kepada publik. Tujuannya adalah agar masyarakat tergerak untuk membeli atau mengkonsumsi produkproduk tersebut. Iklan berusaha berlomba-lomba membangkitkan hasrat konsumen untuk berbelanja bahkan lebih ngeri lagi, konsumen menjadi shopaholic (gemar belanja). Menurut Ratna Noviani (2002: 49), bahwa iklan memberikan rasionalisasi-rasionalisasi yang membenarkan orang untuk tidak sayang mengeluarkan banyak uang dalam berbelanja.

Dewasa ini, iklan tidak hanya menyampaikan pesan penjualan, tetapi juga menyuguhkan hiburan kepada khalayak. Dengan kata lain, iklan diposisikan sebagai sebuah sales entertainment. Dalam peran dan fungsinya itu, iklan banyak menggunakan citra-citra yang dipresentasikan semenarik mungkin guna meningkatkan penjualan. Apabila kita cermati, ikon atau sosok perempuan amat sering ditampilkan sebagai citra dalam iklan. Maraknya penggunaan sosok perempuan dalam iklan memang menjadi fenomena yang sangat menarik untuk dicermati. Banyak ulasan yang merasionalkan kecenderungan tersebut.

Citra yang terkandung di dalamnya, baik secara verbal maupun visual, mempunyai pengaruh besar pada pembentukan rangsangan bagi orang yang melihat (Jaques Lacan, Discourse and Social Change). Judi Uway dari Biro Iklan JCK mengakui, "Untuk iklan-iklan kecantikan, seperti sabun mandi, misalnya, iklan memang menjual imajinasi”. Karena keindahannya pula, untuk iklan sebuah produk yang bobot kehadiran tokohnya sama, antara pria dan perempuan, biasanya perempuanlah yang dipilih. Kriterianya antara lain karena keindahannya, perempuan sering menjadi sumber inspirasi, termasuk dalam melahirkan sebuah produk.

Dunia periklanan (media cetak, elektronik, dan media luar ruang) selalu diramaikan oleh kaum perempuan. Pengiklan (produsen) dan perusahaan periklanan (biro iklan) berpandangan bahwa penggunaan figur perempuan dalam ilustrasi iklan merupakan satu tuntutan estetika untuk memperebutkan perhatian konsumen. Di kalangan pekerja kreatif fenomena tersebut ditanggapi dengan memunculkan beberapa alasan tentang dipilihnya perempuan sebagai bintang iklan yang menjadi juru bicara bagi keberadaan sebuah produk.

Mereka menganggap bahwa perempuan lebih efektif dalam upaya merebut perhatian target audience (khalayak sasaran). Banyak produk yang ditujukan pada konsumen perempuan, baik laki-laki maupun perempuan pada dasarnya menyukai penampilan perempuan yang anggun, santun, dan cantik. Sedangkan sebagian pria menyukai penampilan perempuan yang seksi.

Menurut pengakuan seorang mantan peragawati nasional terkenal, Okky Asokawati, perempuan dan iklan memang tidak bisa dipisahkan. Tidak disangsikan bahwa perempuan memiliki kekuatan dalam membantu menjual produk yang diiklankan kepada konsumen. Ibarat sebuah pertunjukan sandiwara, perempuan merupakan tokoh kunci yang menentukan berhasil tidaknya sebuah iklan. Karena itulah, keberadaan 
Prayanto Widyo Harsanto, Imajinasi Berbasis Gender ...

perempuan dalam iklan selalu menyertai produk paling bersahaja hingga sedan mewah. Baik itu iklan telepon seluler, rokok, sepatu, obat-obatan, makanan, bank, perumahan, lembaga pendidikan, dan busana.

Sabun Lux yang dikampanyekan sejak tahun 1995, pada setiap iklannya menyuguhkan penampilan perempuan-perempuan cantik yang dinobatkan sebagai Bintang Lux. Selain cantik, mereka juga cukup dikenal oleh masyarakat Indonesia. Konsep iklannya adalah menonjolkan gaya hidup seorang bintang, menggunakan modelmodel cantik seperti Tamara Bleszinky, Nadia Hutagalung, Vira Yuniar, dan Desi Ratnasari. Model yang dipakai dalam iklan dianggap bisa mencerminkan citra produk dari sabun Lux.

Atribut, kualitas, atau sikap yang mencirikan keperempuanan sebagai potensi melekat yang dimiliki seorang perempuan secara krodati, kini justru menjadi aset dalam serangkaian produksi dan pasar industri kebudayaan bernama iklan. Keberadaan iklan bahkan telah membangkitkan kembali rasa semacam semangat dan kebahagiaan luar biasa masyarakat yang menghibur diri dengan rangkaian komoditas di etalase kebudayaan populer.

Ada tiga kata yang terlebih dahulu yang perlu dipahami dalam pembahasan ini: estetika, tubuh, dan perempuan. Menurut Gading J. Sianipar dalam buku Teoro-Teori Kebudayaan (2005: 320) mengatakan, Estetika adalah filosofi mengenai sifat dan persepsi tentang keindahan yang dialami si subjek terhadap karya seni baik yang alami maupun karya ciptaan manusia. Sedangkan tubuh adalah keseluruhan jasad manusia dari ujung rambut sampai kaki. Kata "Perempuan” berasal dari kata “empu” yang merujuk pada gelar kehormatan “yang dituankan sebagai berkemampuan”. Bagaimana estetika menilai tubuh perempuan sebagai karya seni alami, dimana tubuh dilihat sebagai bagian keindahaan dari perempuan secara anatomi, simbolik, modal/otoritas, semiotika, dan juga fotografi.

Dalam tulisan ini akan dipaparkan penafsiran terhadap budaya masyarakat kita dengan bertolak dari pemaknaan dan penggunaan tubuh perempuan sebagai simbol yang bersifat publik. Adapun contoh yang diangkat dalam topik ini adalah pemaknaan tubuh perempuan dalam iklan yang begitu banyak menarik perhatian orang. Tubuh perempuan yang dipakai dalam iklan yang telah menciptakan budaya yang imajiner bagi audiencenya. Dalam kajian ini digunakan pendekatan visual methodologies sebagaimana yang dilakukan Gillian Rose (2001), dimana dalam sebuah kajian dengan objek material berupa artefak yang utamanya bisa dilihat, diamati melalui indera penglihatan. Dalam kajian visual terdapat tiga wilayah yaitu dari sisi produksi, karya iklan itu sendiri, dan masyarakat yang mengkonsumsi iklan.

\section{Perempuan dalam Iklan}

Iklan dan perempuan bisa diibaratkan sebagai satu tim yang mempunyai misi untuk mempromosikan suatu produk, masing-masing saling memberi kontribusi. Sering keberadaan iklan yang menggunakan model perempuan menjadi suatu polemik pro dan kontra. Hanya karena ingin mengekspose keindahan (kemolekan tubuh wanita), banyak 
iklan yang terlalu memaksakan diri untuk memunculkan perempuan, meskipun tanpa konteks yang jelas.

Perempuan sering digunakan sebagai model iklan bermacam-macam produk, baik itu produk jasa atau produk barang seperti; sabun, shampoo, snack, mesin cuci sampai mobil bahkan rokok. Posisi, peran, dan kontribusi wanita dalam iklan tersebut sering dimunculkan oleh sang kreator iklan suatu agency dan pihak pengiklan dengan berbagai alasan, yang salah satunnya adalah memberi ataupun menambah daya tarik. Dalam belantara produk yang muncul ditengah-tengah masyarakat consumer dewasa ini, iklan tidak sekedar berfungsi menawarkan dan mempengaruhi target sasarannya untuk membeli barang atau menggunakan jasa, tetapi juga membentuk suatu pertunjukan (tontonan) yang diisi dengan berbagai tanda, citra, dan makna. Menurut Haug yang dikutip Yasraf A. Piliang (2003: 289), dalam iklan terdapat rangkaian-rangkaian ilusi yang disuntikkan pada sebuah komoditi, dalam rangka mengendalikan konsumen, seperti suntikan bius yang membuat terlena.

Penggunaan model perempuan yang memicu protes dikalangan masyarakat karena terlalu vulgar, dapat kita jumpai di tabloid ataupun majalah yang bisa dikatakan panas. Tabloid atau majalah tersebut sampai sekarang juga masih diperjual-belikan di kios-kios pinggir jalan ataupun gerai-gerai supermarket, sebut saja untuk kategori tabloid: Seksi, Bos, Pop, Hot, Lipstick, Wow, Blitz, Buah bibir dan untuk kategori majalah: Top, Hoki, Liberty, Seksi dan Play Boy versi Indonesia yang baru saja terbit dan mendapatkan kritik dari berbagai kalangan, dan mungkin masih banyak lagi. Peran dan fungsi wanita dalam cover tabloid atau majalah panas tersebut sebenarnya jauh dari sifat anggun dan santun, akan tetapi mengarah ke sesuatu yang bersifat libidinal. Fenomena ini bisa dikatakan masuk akal, karena sasaran yang dituju adalah kaum adam. Jadi tak mengherankan jika dari cover sampai halaman dalamnya hanya menyajikan wanita dengan pose dan busana yang vulgar.

Pariwara yang memuat kandungan seksual, dengan menggunakan model wanita memiliki peran tersendiri. Pertama menarik perhatian (attentional lure) dan mampu menjaga perhatian dalam jangka waktu yang lebih panjang, Kedua dapat meningkatkan recall jika cocok dengan kategori produk dan eksekusi kreatif periklanan, Ketiga mampu membangkitkan respon emosional. Jadi, sesungguhnya unsur perempuan dalam iklan memang sangat berpengaruh dalam komunikasi pemasaran meskipun tidak asal diumbar begitu saja.

Dalam konteks ini menjadi menarik untuk mengetahui, bahwa tampilan wanita cantik dan seksi ternyata tidak saja memikat khalayak laki-laki, namun juga perempuan. Menurut Helen Gurley Brown, pendiri majalah Cosmopolitan yang dikutip majalah cakram, perempuan juga senang memperhatikan model yang cantik dan seksi, karena dapat menjadikan mereka semacam brand marking. Penelitian yang dilakukan Elliot dan Ritson (1995), memperlihatkan bahwa pencitraan seksual dalam periklanan telah diadaptasi sedemikian rupa dalam praktik-praktik sosial kelompok-kelompok masyarakat. Representasi seks dalam iklan dimungkinkan wanita lebih mudah menyampaikan keinginan mereka dalam mengonsumsi advertising meaning dan memanfaatkannya sebagai komoditas kultural (Cakram, Sept. 2001). 
Prayanto Widyo Harsanto, Imajinasi Berbasis Gender ...

\section{Pembahasan}

\section{Citra Perempuan dalam Iklan}

Dalam pola konsumsi di masyarakat, kita telah memasuki tatanan bahwa konsumsi telah merefleksikan citra. Mobil, busana, parfum, es krim, bahkan sabun mandi telah diciptakan dan dikomunikasikan sedemikian rupa untuk mewakili personifikasi Anda. Dalam konteks pemasaran, hal ini diwakili oleh merek, yang berjiwa dan memiliki roh, sehingga dapat menjadi tua dan lapuk jika tidak dijaga baik-baik. Dalam wacana post modern, pencitraan merupakan cara yang penting untuk mengemas ide untuk dijadikan sebagai memori publik untuk mengendalikan diri mereka.



Perempuan yang digunakan dalam iklan XO ini selain sebagai daya tari visual namun juga membawa pemaknaan tersendiri serta membawa imajinasi bagi audiencenya.

Dalam hal ini juga bisa diamati pada iklan mobil yang menggunakan model perempuan cantik sebagai salah satuw ilustrasi pada iklan mobil Toyota VIOS 1. 


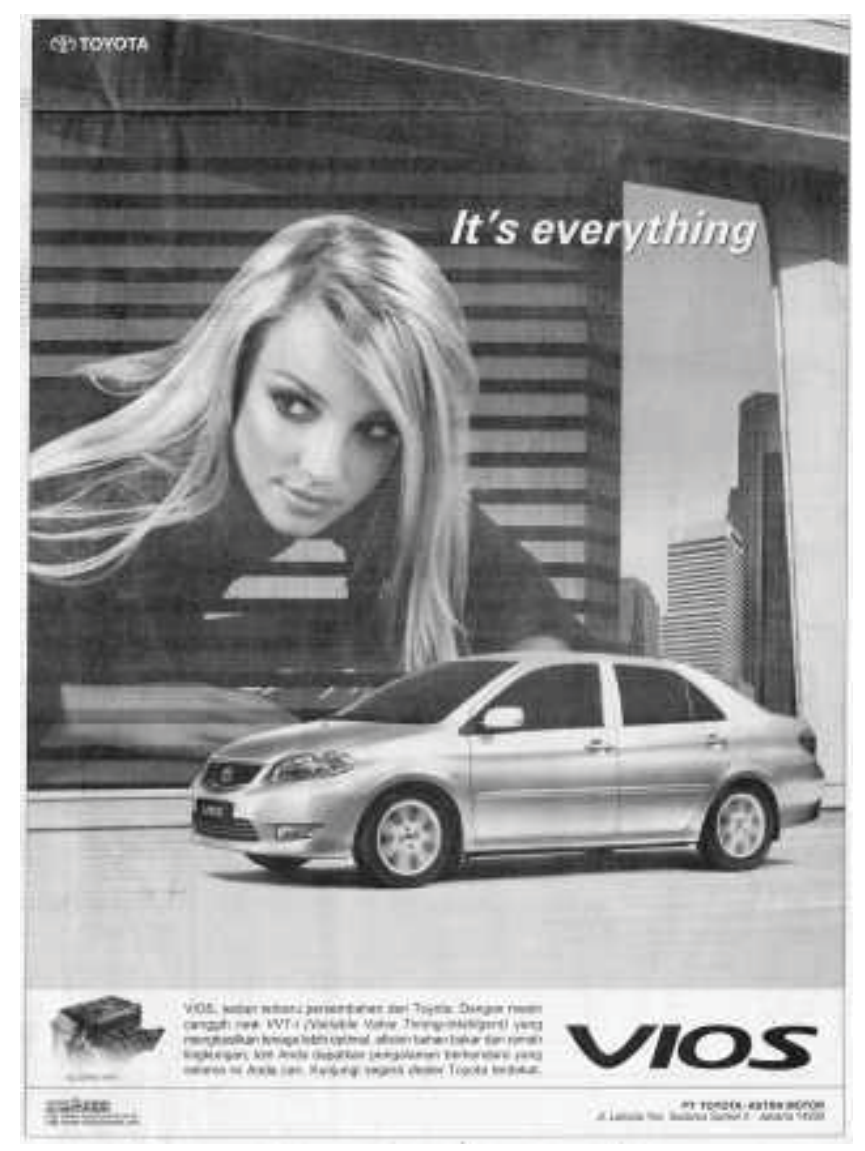

Dalam iklan ini perusahaan berusaha memberikan pencitraannya pada produk terbarunya. Toyota Vios 1 merupakan andalan baru Toyota di kelas sedan mini, menggantikan Toyota Soluna.

Kesan yang muncul dari iklan ini adalah sebuah suasana kehidupan moderen. Iklan ini menampilkan seorang perempuan berambut pirang yang diidentikan dengan bule, simbol dari west life atau kehidupan barat. Negara-negara barat adalah negaranegara maju, yang selalu menjadi tolok ukur untuk menilai sebuah kemajuan atau kemodernan pada negara-negara berkembang dan negara-negara lain yang tingkat perkembangannya lebih rendah. Contoh dari kecenderungan melihat negara-negara barat misalnya adalah adanya tren anak muda Indonesia sekarang yang banyak mengecat rambutnya dengan warna pirang, coklat, agar terkesan londo dan gaul. Rambut yang dibiarkan tergerai jatuh, dengan belahan sebelah kiri dan sedikit poni mengesankan sebuah perempuan yang punya pola pikir apa adanya dalam menyikapi tren dalam aktivitas keseharian.

Rias wajah yang tipis tidak menor tetapi tetap kelihatan cantik menggambarkan seorang perempuan eksekutif dengan irama kerja yang tinggi, aktif, dinamis, dan sangat menghargai waktu sehingga untuk berlama-lama di meja rias pun tidak sempat. Selain itu, perempuan masa kini mulai terjangkiti tren wajah sehat segar berseri-seri karena hasil dari pola hidup sehat, olahraga teratur (senam, body language, spa), dan istirahat yang 
Prayanto Widyo Harsanto, Imajinasi Berbasis Gender ...

cukup, sehingga wajah tetap cantik dan tidak memerlukan kosmetika yang berlebihan. Senyum tipis dengan bibir mengatup mengesankan sebuah optimisme dan kepercayaan diri yang tinggi.

Dapat ditarik kesimpulan bahwa di dalam iklan komersial Toyota VIOS ini terdapat tali hubungan yang erat antara tanda dan pesan. Keduanya saling melengkapi. Tali hubungan yang erat antara tanda dan pesan pada iklan ini yaitu bahwa keduanya sama-sama memberikan nuansa modern. Moderen berarti pula sempurna, mewah, segalanya ada (headline). Iklan ini menawarkan mobil yang mampu memberikan segalanya, dari desain bodi yang oke, interior yang elegan, mesin yang prima, hingga keamanan mengendarainya. Penggunaan model perempuan berambut pirang yang diidentikkan dengan bule, simbol dari west life atau kehidupan barat. Negara-negara barat adalah negara-negara maju, yang selalu menjadi tolok ukur untuk menilai sebuah kemajuan atau kemodernan di negara-negara berkembang dan negara-negara lain yang tingkat perkembangannya lebih rendah. Kesan modern didukung pula oleh kehadiran ikon gedung pencakar langit.

Salah satu bentuk nyata dari pemahaman terhadap pentingnya merek, tampil dalam momen-momen tontonan (spectacle) dimana seseorang ingin melihat dan dilihat dalam masyarakat kecilnya. Maka produk tak lagi dimanfaatkan sebagaimana fungsinya namun lebih kepada manfaat emosionalnya. Dengan cara ini komoditi betul-betul menjadi spectacle yang menciptakan masyarakat tontonan, yang mendorong masyarakat konsumen untuk lebih intens mengonsumsi tontonan, dan bukan fungsi dari merek yang mereka beli. Demikian pula sama-sama iklan mobil, setiap iklan memiliki segmen tersendri, seperti iklan mobil SUZUKI AERIO MY MPV.

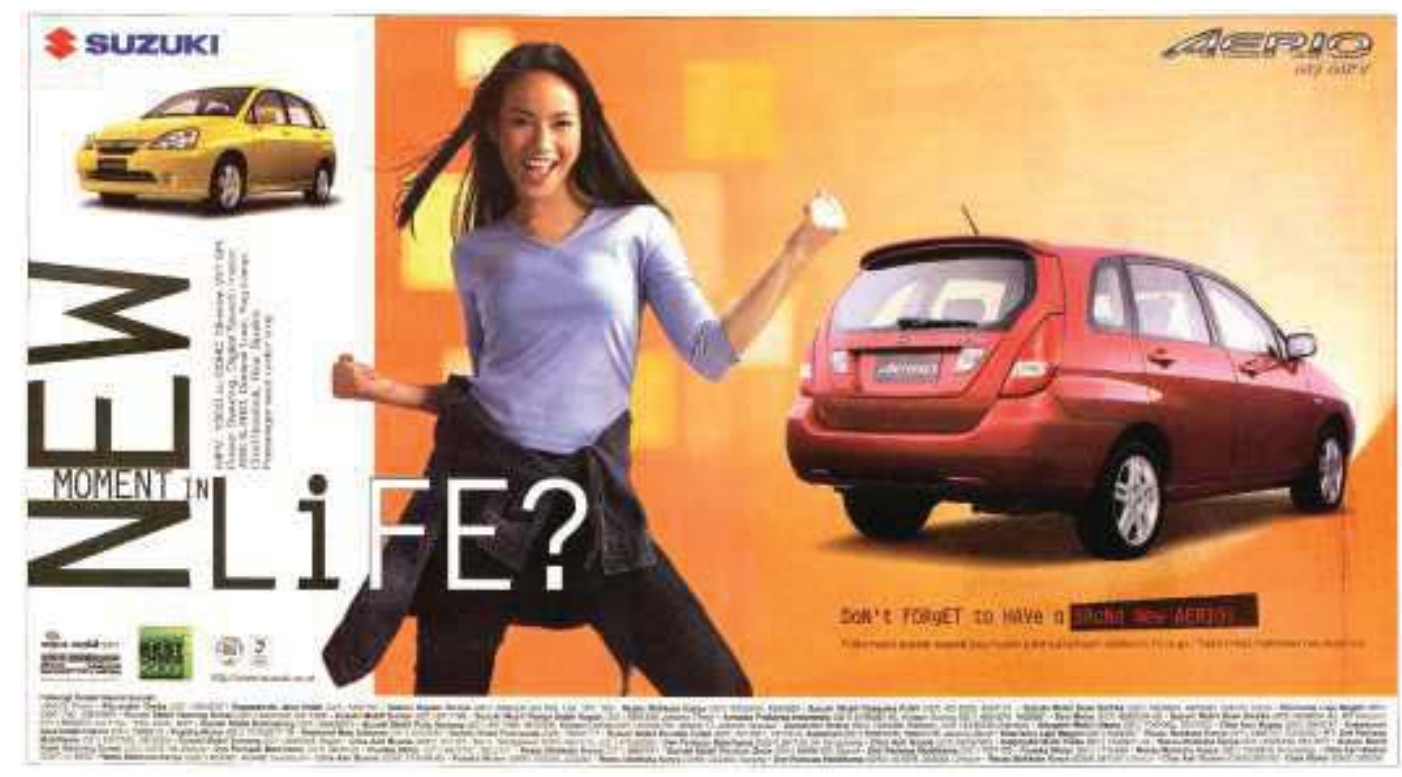

Dalam iklan ini diceritakan bahwa si perempuan sedang mengalami keberhasilan dalam hidup yang tentunya hasil kerja kerasnya selama ini, dan untuk menikmatinya dia butuh sebuah mobil yang mampu menemaninya setiap saat. Ikon perempuan dalam iklan 
ini mengandung kode semantik, yaitu kode yang mengandung makna konotasi pada level penanda. Perempuan memberikan makna konotasi feminitas.

Berdasarkan analisa di atas dapat ditarik kesimpulan bahwa di dalam iklan komersial Suzuki Aerio My MPV ini terdapat tali hubungan yang erat antara tanda dan pesan. Keduanya saling melengkapi. Pesannya adalah bahwa mobil Suzuki Aerio My MVP adalah mobil yang cocok sebagai teman untuk menikmati kebebasan (keberhasilan). Dalam iklan ini perempuan dipakai sebagai tokoh sentral yang berfungsi menyampaikan pesan tentang keberhasilan mengubah hidup. Perubahan hidup yang baik ditandai dengan lepasnya belenggu kesengsaraan yang ada, mampu menemukan jalan keluar yang baik, sehingga bisa lebih bebas untuk maju. Perempuan yang sifatnya lemah menumbuhsuburkan dominasi kaum laki-laki untuk melakukan penindasan. Pelecehan seksual, pemerkosaan, dan penomorduaan status baik di dalam keluarga ataupun masyarakat adalah beberapa contoh konkretnya.

Kajian ini menggunakan analisa ikonografis. Menurut Erwin Panofsky dalam bukunya "Meaning in The Visual Arts", pengertian dari analisa ikonografis (iconographical analysis) adalah secondary or conventional subject matter, constituting the world of images, stories and allegories. Sebelum sampai tahap analisis ikonografis, perlu dilakukan analisa deskriptif terlebih dahulu yang disebut pre iconographical description atau deskripsi pra ikonografis, yaitu primary or natural subject matter, (A) Factual, (B) Expressional constituting the world of artistics motifs (line, color, volume). Setelah dilakukan analisa ikonografis, tahap selanjutnya adalah interpretasi ikonologik (iconological interpretation). Pengertian dari iconogical interpretation adalah intrinsic meaning or content, contituting the world of "symbolical" values. Jadi analisa ikonografis (iconographical analysis) lebih menekankan pada aspek bentuk, sedangkan interpretasi ikonologik (iconological interpretation) terletak pada aspek isi.

Dalam tampilan yang cenderung bersifat narsisisme itu, tak perlu heran jika hanya ada batas tipis terhadap dorongan untuk memamerkan keindahan tubuh. Eksplorasi potensi tubuh (libidinal power) ini kemudian memperoleh tempat yang sangat wajar dalam konteks kehidupan permisif di masa-masa posmoderenisme. Hal ini dapat dengan mudah kita saksikan dalam rangkaian foto-foto seronok di banyak majalah gaya hidup dan tabloid. Dalam konteks ini menjadi menarik untuk mengetahui bahwa tampilan wanita yang cantik dan seksi ternyata tidak saja memikat khalayak lelaki, namun juga perempuan. Helen Gurley Brown, pendiri majalah Cosmopolitan menyebutkan bahwa perempuan juga senang memperhatikan model yang cantik dan seksi karena dapat menjadikan mereka sebagai semacam benchmarking.

Iklan-iklan yang menampilkan perempuan dalam iklan sebagai citra peraduan dikritik lahir dari tangan perancang iklan pria. Kritik ini biasanya menyebutkan bahwa hal ini sering terjadi karena dominasi pria di media, sehingga mereka mampu 'melecehkan' wanita. Selain citra peraduan, perempuan juga ditampilkan dalam citra pigura, citra pilar, citra pinggan, dan citra pergaulan. Sampai di sini, mitos bahwa pencitraan perempuan dalam kelima pencitraan tersebut karena ulah tangan-tangan pria yang berkuasa di media maupun di periklanan mungkin dapat kita bantah.

Pencitraan perempuan seperti ini mudah dapat kita saksikan di media perempuan semacam Femina, Dewi, atau Cosmopolitan. Bahkan iklan-iklan yang menampilkan 
Prayanto Widyo Harsanto, Imajinasi Berbasis Gender ...

perempuan dalam kelima citra tersebut banyak di antaranya dirancang oleh pembina usaha atau pengarah kreatif perempuan. Mereka melakukan pencitraan semacam itu karena suatu alasan yang sangat mendasar: begitulah cara yang terbaik untuk menciptakan stimuli agar khalayak yang diincar merespon pesan yang disampaikan. Begitulah memang langgam kehidupan khalayak sasaran mereka. Pendekatan serupa dilakukan iklan-iklan yang mencitrakan perempuan untuk tampil memikat dengan mempertegas kecantikan fisik yang dimilikinya (citra pigura). Atau citra pilar memperlihatkan wanita di sektor domestik sebagai perawat keluarga. Kita tahu, deterjen Surf dengan pendekatan semacam itu berhasil memasuki pasar meski harus bersaing keras dengan Daia.

Boleh dibilang iklan adalah cermin dari langgam kehidupan masyarakatnya. Untuk dapat berhasil iklan harus masuk ke dalam idiom-idiom khalayak sasarannya. Jika tidak, ia akan teralienasi, dan pesan-pesan yang disampaikannya akan semata menjadi pemborosan belaka. Sejumlah penelitian memang membuktikan bahwa bintang iklan cantik yang tampil di layar kaca maupun media cetak berhasil menjual produk lebih banyak. Sejumlah studi empiris menjelaskan fenomena ini, memperlihatkan bahwa daya tarik ragawi dalam iklan dapat meningkatkan kepercayaan terhadap pengiklan, kemauan untuk membeli, sikap terhadap produk, dan actual purchase.

\section{Konsep tentang Kecantikan}

Kecantikan itu sendiri telah menjadi diskursus sejak Plato dan Aristoteles. Bagi Plato, dunia yang kita kenal bukan kebenaran yang sesungguhnya. Seni dan kecantikan hanya peniruan dari imitasi bentuk keduniawian yang sebenarnya. Yang disebutnya sebagai beholding beauty with the eye of the mind.

Aristoteles justru beranggapan kecantikan bersifat alamiah. Kecantikan dan kebaikan adalah suatu hal yang serupa. Menurutnya kecantikan dan kebaikan bersifat alamiah dan merupakan awal dari pengetahuan dan pergerakan untuk banyak hal dalam kehidupan. (Eric Fernie, 1995: 214).

Hal ini menjelaskan kecantikan ternyata memiliki peran penting sejak awal manusia membangun kebudayaannya. Karena itu tak perlu heran jika wanita-wanita cantik menjadi idola, pemujaan (cult), dan menjadi simbol penting dalam kebudayaan popular. Meskipun, seperti disebut Aristoteles, kecantikan bersifat sama bagi pria dan wanita, dalam periklanan wanita-wanita cantik yang lebih sering dimanfaatkan sebagai bintang iklan. Hal ini tampaknya karena wanita cantik memberikan dukungan terhadap produk, dimana wanita maupun pria menyenanginya. Keindahan yang terdapat pada perempuan berbeda dengan keindahan yang terdapat pada tubuh laki-laki. Keindahan yang khas dari perempuan memuat cita rasa yang estetis yang unik (Teori -Teori Kebudayaan, 2005: 316).

Helen Gurley Brown, pendiri Cosmopolitan menjelaskan bahwa tampilan wanita cantik dan seksi di sampul majalahnya disenangi oleh perempuan yang menjadi khalayak sasarannya. "Mereka mengapresiasi model yang ditampilkan dan menjadikannya sebagai contoh kecantikan yang pantas untuk ditiru,” katanya kepada penulis. Sampai di sini menjadi menarik untuk diketahui, sejauh mana model-model cantik ini dapat membantu 
menjual produk yang diiklankan. Apakah kehadiran wanita-wanita cantik ini dapat menjual beragam produk yang memiliki karakter berbeda-beda? Beberapa penelitian memperlihatkan bahwa kecantikan semata tidak menjamin akan membantu mendorong penjualan produk. Faktor gender, tingkat kecantikan, maupun personalitas model ikut mempengaruhi. Di sinilah pentingnya untuk menyiasati penggunaan model cantik dalam iklan. Produk-produk yang sesuai dengan persepsi khalayak sasarannya cenderung akan memberikan recall yang baik.

Tingginya keinginan pria untuk membeli parfum dengan model wanita cantik, misalnya, muncul karena ada semacam impian dan fantasi tentang kehangatan seksual dengan model wanita cantik yang ditampilkan dalam iklan. Sebaliknya, keinginan mereka untuk membeli kopi setelah menyaksikan model yang kurang atraktif, bisa muncul karena persepsi mereka mengenai perempuan yang memang pintar membuat kopi. Hal ini menjelaskan bahwa wanita cantik yang menjadi model iklan haruslah relevan dengan produk yang diiklankannya.

Selain itu, tampilan fisik, sikap perilaku model, keintiman diantara model, figur dan konteks juga dapat mempengaruhi respon konsumen. Busana yang digunakan, sensualitas, model tampil sendiri atau berpasangan, memberikan pengaruh pada persepsi khalayak sasaran. Hal semacam ini perlu dipertimbangkan dengan seksama agar pesan yang disampaikan dapat diterima dengan baik oleh khalayak sasaran. Di sinilah pentingnya memiliki pengarah seni yang memahami cara menciptakan mood dalam pesan yang akan disampaikan. Suatu eksekusi model yang memiliki kecantikan ragawi, namun dilakukan secara vulgar tentu akan memberikan dampak negatif. Seperti terbukti bahwa iklan yang menampilkan wanita telanjang produknya dianggap berkualitas rendah.

Dalam konteks kecantikan ragawi, konsumen memang kerap terperdaya pada apa yang disebut Baudrilard sebagai spectacie dan simulacra, dimana konsumen ingin tampil cantik agar ditonton. Konsumsi semacam ini melahirkan commodity fetishism, dimana produk dianggap menciptakan prestise dan otoritas. Itu sebanya produk-produk simbol status kerap memanfaatkan appeal kecantikan ragawi yang memikat.

Perkembangan kultur spectacle memang telah mengembangkan budaya konsumen, dimana imaji visual dan realitas runtuh. Masyarakat tontonan menciptakan narsisisme budaya yang mendorong kemauan mengeksplorasi potensi tubuh (libidinal power) sebagai tontonan untuk menjual komoditi. Libidinal economy menciptakan logic of desire (logika hasrat) yang dilepaskan dalam bentuk-bentuk komoditi, dimana potensi enerji libido dan hasrat diwakili.

Begitulan iklan yang menampilan kecantikan ragawi akhirnya muncul secara nyata dalam kancah periklanan. Suatu upaya pemasar untuk merengkuh khalayak sasarannya. Kecantikan lahiriah seorang wanita memang subjektif. Tidak ada kriteria yang baku. Hanya saja karena persoalan ini merupakan kisah lama maka tidak sulit bagi pria untuk menilai seorang perempuan itu sempurna atau sedang-sedang saja. Dan asyiknya, perempuan cantik mampu membuat laki-laki merasa menjadi pria sejati. Pemahaman kuno mengatakan, ada tiga hal yang bisa mempengaruhi kecantikan kaum hawa yakni body (tubuh), soul (jiwa), dan spirit (semangat). Bila ketiga faktor itu muncul ke permukaan dalam bentuk positif, maka ia mampu mengubah aura tubuh kelompok 
Prayanto Widyo Harsanto, Imajinasi Berbasis Gender ...

feminis menjadi menyenangkan. Inilah yang sering disebut inner beauty alias kecantikan batiniah.

\section{Kesimpulan}

Berdasarkan tulisan di atas yang membahas tentang iklan komersial yang menggunakan model perempuan, maka dapat dikemukakan suatu kesimpulan bahwa, sebuah iklan mampu memberikan dorongan bagi audience-nya membentuk/menciptakan imajinasi atau khayalan sesuai dengan tujuan yang ingin dicapai dalam komunikasi. Iklan adalah hasil kebudayaan moderen disadari atau tidak mempengaruhi tingkah laku masyarakat. Model perempuan yang digunakan sebagai model iklan dapat membangkitkan daya tarik pada pandangan pertama, dimana hal ini sesuai yang diharapkan sebuah iklan adalah mampu menarik perhatian. Perempuan juga berfungsi sebagai nyawa dari suatu produk atau jasa yang ditawarkan.

Perempuan digunakan sebagai obyek utama untuk membangkitkan daya tarik erotik terhadap sebuah produk, sehingga produk yang ditawarkan diharapkan mampu terjual atau mampu mendongkrak penjualan. Demikian pula halnya bahwa tubuh perempuan disegmentasi menjadi elemen-elemen tanda (mata, bibir, hidung, rambut, payudara, kulit, pinggul) yang masing-masing mampu menghasilkan makna yang laku dijual: sensual, erotis, menggairahkan, pesona, fetis. Dalam hal ini estetika menilai tubuh perempuan sebagai karya seni alami, dimana tubuh dilihat sebagai bagian keindahaan dari perempuan secara anatomi, simbolik, modal/otoritas, semiotika, dan juga fotografi.

Tubuh seorang perempuan telah menjadi milik publik yang tampak dari cara tubuh perempuan ditampilkan. Iklan yang menonjolkan bentuk, penampilan, dan keindahan tubuh ditayangkan ke publik dimana proses belajar berlangsung. Pada saat terjadi pergeseran dari dunia privat ke publik terjadi pula pergeseran citra tentang perempuan, namun yang menarik adalah proses ini tidak menyebabkan terbentuknya potret perempuan yang baru, tetapi lebih merupakan "penegasan kembali” potret lama dimana perempuan merupakan obyek seks.

\section{Kepustakaan}

Fernie, Eric. 1995. Art History and its Methods a Criticle Anthology. London: Phadon Press Limited.

Novianti, Ratna. 2002. Jalan Tengah Memahami Iklan: Antara Realitas, Representasi dan Simulasi, Yogyakarta: Pustaka Pelajar.

Panofsky, Erwin. 1955. Meaning in the Visual Arts. Chicago: The University of Chicago Press.

Piliang, Yasraf Amir. 2003. Hipersemiotika. Tafsir Cultural Studies Atas Matinya Makna. Yogyakarta: Jalasutra.

Piliang, Yarsraf Amir. 1998. Sebuah Dunia yang Dilipat, Realitas Kebudayaan Menjelang Millenium Ketiga dan Matinya Postmodernisme. Bandung: Penerbit Mizan. 
Jurnal Invensi Vol. 2 No. 2 Desember 2017

Sutrisno, Muji. 2005. Teori-Teori Kebudayaan. Yogyakarta: Penerbit Kanisius.

Storey, John. 2008. Cultural Studies dan Kajian Budaya Pop. Yogyakarta: Jalasutra. Williams, Raymond. 1983. Culture. Britain: Fountana Paperbacks.

, Cakram, Edisi September 2001. 